\title{
Communication \\ Food Loss and Food Waste for Green Cosmetics and Medical Devices for a Cleaner Planet
}

\author{
Pierfrancesco Morganti ${ }^{1,2, *}$, Xinghua Gao ${ }^{3}{ }^{-}$, Natalia Vukovic ${ }^{4}{ }^{(}$, , Alessandro Gagliardini ${ }^{5}$, Alka Lohani ${ }^{6}$ \\ and Gianluca Morganti ${ }^{7}$
}

Citation: Morganti, P.; Gao, X.; Vukovic, N.; Gagliardini, A.; Lohani, A.; Morganti, G. Food Loss and Food Waste for Green Cosmetics and Medical Devices for a Cleaner Planet. Cosmetics 2022, 9, 19.

https://doi.org/

$10.3390 /$ cosmetics 9010019

Academic Editor: Enzo Berardesca

Received: 13 December 2021

Accepted: 20 January 2022

Published: 28 January 2022

Publisher's Note: MDPI stays neutral with regard to jurisdictional claims in published maps and institutional affiliations.

Copyright: (C) 2022 by the authors. Licensee MDPI, Basel, Switzerland. This article is an open access article distributed under the terms and conditions of the Creative Commons Attribution (CC BY) license (https:// creativecommons.org/licenses/by/ $4.0 /)$.
1 Research and Development Unit, Academy of History of Healthcare Art, 00186 Rome, Italy

2 Dermatological Department, China Medical University, Shenyang 110001, China

3 Dermatological Department, The First Hospital of China Medical University, Shenyang 110001, China; gaobarry@hotmail.com

4 Laboratory of International and Regional Economics, Graduate School of Economics and Management, Ural Federal University, 620000 Ekaterinburg, Russia; shpak17121978@gmail.com

5 Research and Development Unit Texol Srl, 65020 Alanno, Italy; alessandro.gagliardini@texol.it

6 School of Pharmaceutical Sciences Moradabad, IFTM University, Moradabad 244001, India; alkalohani06@gmail.com

7 ISCD Nanoscience Center, 00165 Rome, Italy; lucamorgan@libero.it

* Correspondence: pierfrancesco.morganti@iscd.it

\begin{abstract}
To stay wealthy in a world where all can live in prosperity and wellbeing, it is necessary to develop sustainable growth at net zero emissions to stop climate change, neutralizing both risks and diseases such as the COVID-19 pandemic and inequalities. Changing the worldwide use of the great quantity of food loss and waste can help to move in this direction. At this purpose, it seems useful to transform food waste into richness, extracting and using its content in natural ingredients and biopolymers to make new sustainable products and goods, including cosmetics and medical devices. Many of these ingredients are not only bioactive molecules considered of interest to produce these consumer products but are also useful in reducing the environmental footprint. The active agents may be obtained, for example, from waste material such as grapes or olive pomace, which include, among others natural polymers, phythosterols, vitamins, minerals and unsaturated fatty acids. Among the polymers, chitin and lignin have shown particular interest because biodegradable, nontoxic, skinand environmentally friendly ingredients can be obtained at low cost from food and forestry waste, respectively. According to our experience, these polymers may be used to make nanocomposites and micro-nanoparticles that encapsulate different active ingredients, and which may be embedded into gel and non-woven tissues to realize advanced medications and smart cosmeceuticals. However, to utilize food waste in the best possible way, a better education of both industry and the consumer is considered necessary, introducing all to change the ways of production and living. The consumer has to understand the need to privilege, food, cosmetics and goods by selecting products known to be effective that also have a low release of carbon dioxide. Thus, they must pay heed to purchasing cosmetics and medical devices made by natural ingredients and packaged by biodegradable and/or reusable containers that are possibly plastic free. Conversely, the industry must try to use natural raw materials obtained from waste by changing their actual production methods. Therefore, both industry and the consumer should depart from the linear economy, which is based on taking, making, and producing waste, to move into a circular economy, which is based on redesigning, reducing, reusing and recycling. Some examples will report on the possibility to use natural polymers, including chitin and lignin, to produce new cosmeceutical tissues. These innovative tissues, to be used as biodegradable carriers for making smart cosmetics and medical devices, may be produced at zero waste to save our health and the planet biodiversity.
\end{abstract}

Keywords: waste; food loss; polysaccharides; chitin nanofibrils; lignin; greenhouse gas; carbon dioxide; methane; plastics; nanocomposites; biopolymers; natural ingredients; cosmeceutical-tissues; cosmetics; medical device; beauty market 


\section{Introduction}

Global food lost and waste, which represent about $17 \%$ of the productive process, has become a big problem, with a cost of USD 2.6 trillion annually, which is enough to feed the millions of undernourished people in the world [1-3]. This waste averages around 931 million tons each year, $61 \%$ of which comes from households, $26 \%$ from food service and $13 \%$ from retail. Moreover, according to the United Nations report, the unconsumed food that ranges from $8-10 \%$ and releases part of global carbon emissions [2], has enormously increased after the industrial revolution (Figure 1) [4]. In addition to carbon dioxide $\left(\mathrm{CO}_{2}\right)$, anthropogenic methane $\left(\mathrm{CH}_{4}\right)$ emissions represent the second-largest driver of global warming, accounting for roughly $30 \%$ of the temperature increase [5]. Additionally, while $\mathrm{CH}_{4}$ stays in the atmosphere for only about ten years, $\mathrm{CO}_{2}$ stays in the atmosphere for centuries.

\section{Atmospheric $\mathrm{CO}_{2}$ has risen dramatically over the past 200 years.}

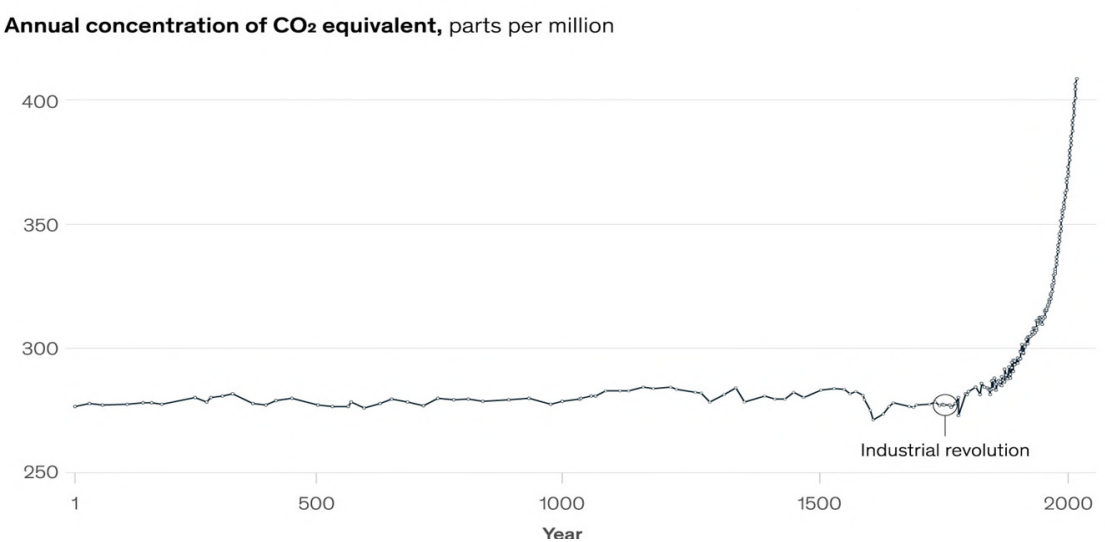

Figure 1. Atmospheric carbon dioxide concentrations during past and present years (Reprinted with permission from Doer and Narisetti (2021). 2021 McKinsey Global Publishing [4]).

Because of these emissions, the global temperature in 2021 resulted in a 1.1 degree centigrade higher temperature than preindustrial levels because of global greenhouse gas (GHG) emissions (Figure 2), and part of these emissions are represented from methane (CH4) [5]. $\mathrm{CH} 4$ comes from millions of agricultural farms around the world as the result of ruminant animals together with farming practices and rice production [1,2]. Carbon dioxide comes from the consumption of our actual household goods, food, dietary supplements, cosmetics and medical devices, which are connected to our actual way of living [6,7].

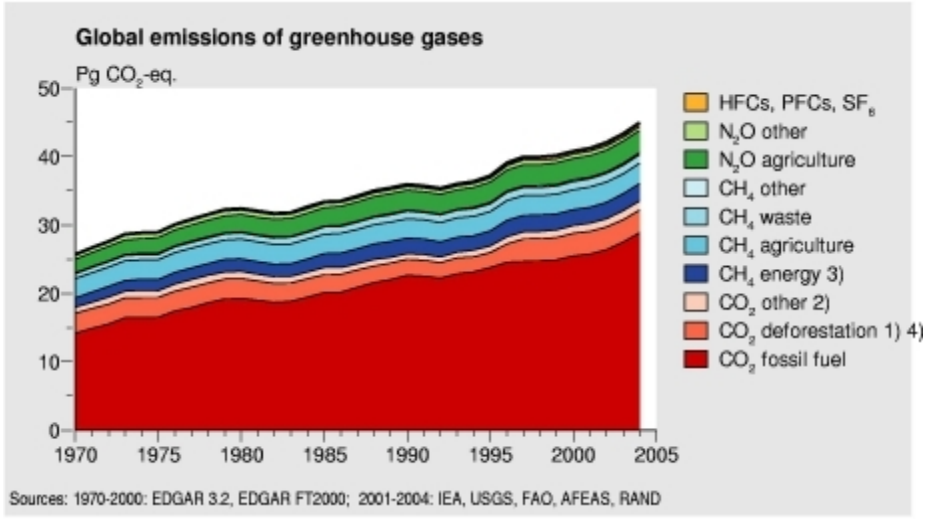

Figure 2. Global greenhouse (GHG) gas emissions.

As a consequence the urgent need to change and select all the purchased products for trying to eliminate waste coming from their formulations' ingredients and plastic-made 
packagings, thus reducing the $\mathrm{CO} 2$ and $\mathrm{CH} 4$ emissions [8]. So doing it will be possible to organize a wellness economy eliminating any kind of waste and pollution, recycling food loss and reducing waste provoked from the plastic packagings also [9]. Global waste, in fact, has notably increased during the COVID-19 pandemic for two principal reasons: a drop in demand in restaurants, closed all the day and full of unconsumed and spoiled ailments, and a major contemporary take-away food used from consumers for the imposed lockdown [10].This unusual consume of food, in fact, packed in containers made by non recyclable polymers has further increased the quantity of non biodegradable plastics invading land and ocean, provoked by billion of non-degradable products, including medical devices, food and cosmetics' packagings [11-13]. As for food, the cosmetic products release in the environment non biodegradable ingredients and plastic waste materials coming from the personal care and make up formulations which, including, viscosity, suspending and scrubbing agents, are packed by plastic containers estimated to be globally and yearly more than 120 billion units [14-21]. At this purpose, it is to remember the great problem of microplastics (MP) in oceans, ranging 1.8 trillion of peaces with an estimated global weight of 80,000 tons. MP debris, in fact, is ingested as toxic food from millions of marine mammals and birds, entering in the human food chain with the consequent release and bioaccumulation of toxic ingredients, including phthalates, phenolic compounds and polybrominated diphenyl ethers (PBDE) many of which are endocrine disrupting chemicals, capable to alter the homeostasis of the human immune system (Figure 3) [11-13,19]. At this purpose, it is to underline that billion of microplastics have been recovered not only into the tea-cups consumed daily from million people [22], but also into the human placenta [23]. On the other hand, fortunately, the coronavirus due to social distancing and lockdown, has kept people inside with a consequential decrease of the general pollution' levels, that for example in China was reduced by $25 \%$ [5].

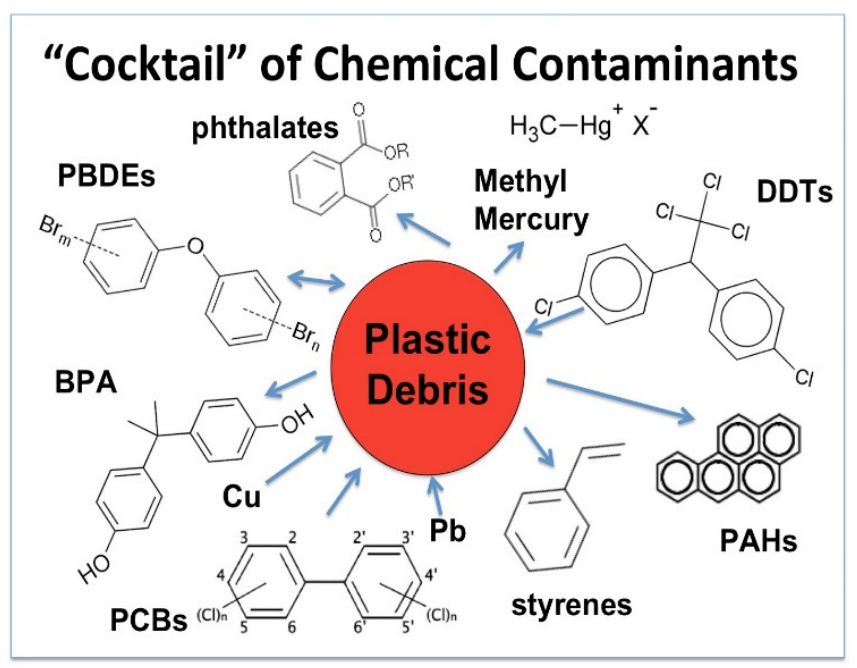

Figure 3. Toxic ingredients in microplastics (Reprinted with permission from The Ocean Foundation and earthDECKS).

However, pandemic, health and climate change are inextricably linked each other, so the need of an healthy body in an healthy planet by the use of biodegradable products, including cosmetics and medical devices. Moreover, there is a necessity to produce more food for the previsional worldwide population growth to 9.7 billion by 2050, realizing also well structured healthy green areas into the cities to neutralize the continuous increasing of the GHG emissions [24]. Therefore the urgent necessity to organize a more efficient food production chain and a better health care and cosmetic system by the use of natural biodegradable ingredients and containers as well as to built a greater resilience against the climate changing, modifying the way to produce and consume. 
Consequently, preventing diseases and environmental disasters became a must of our society: prevention is better than cure both for virus and extreme weather.

In conclusion, eliminating food waste at all levels, including consumer and domestic, and using its content in active ingredients to make cosmetic and medical device also, became today a further necessity. So doing it will be possible to save precious natural resources and avoid the methane and carbon dioxide emissions, obtaining significant environment, social and economic benefits. Moreover, another need is not only to change the food supply chain, but also modify our nutritional habits selecting as much possible, the food at lower impact on $\mathrm{CO}_{2}$ emissions (Figure 4) [4]. Additionally, there is also the urgent hard job to utilize the actual million tons of by-products coming from both the industrial food chain and the forestry waste. This waste material might be used for making different and safe goods, innovative cosmetics, surgical and beauty masks and one-use only medical dressings, incentivizing and increasing the food systems' transformation [19,25-29]. Industrial as well as the in-house food waste, in fact, are rich of proteins, sugars, carotenoids, vitamins, lignans, polysaccharides and various natural-derived polymers, precious ingredients to produce drugs, medical devices, cosmetic products, diet supplements, and innovative biodegradable tissues [25-35]. Among the fibers that may be obtained from food waste there are many natural polymers, including chitin/chitosan, lignins and pullulan by which it could be possible to make, for example, specialized medical dressings, bio colors and bioflavors for the nutraceutical an cosmetic sectors, cosmetic beauty masks and smart tissues to be used as innovative active carriers also [36-38]. As will be focused thereafter, our research group has realized innovative carrier complexes made by chitin nanofibrils with different anionic polymers as nanolignin (CN-LG), verifying their physicochemical characteristics and biological effectiveness when used for cosmeceutical products and medical devices $[39,40]$. Moreover, regarding the CN-LG complex, being easily metabolized from the environment and human enzymes to active ingredients such as glucosamine, acetyl-glucosamine, glucose and polyohenols, these derived molecules could be utilized from the skin cells as food and energy. Consequently, CN-LG acts both as carrier, due to its possibility to entrap active ingredients into its structure and as active compound when the complex is hydrolyzed to its single units [39-41].

\section{Livestock supply chains are an important contributor to climate change.}

Greenhouse-gas emissions produced per kilogram of food product, kilogram $\mathrm{CO}_{2}$ equivalent
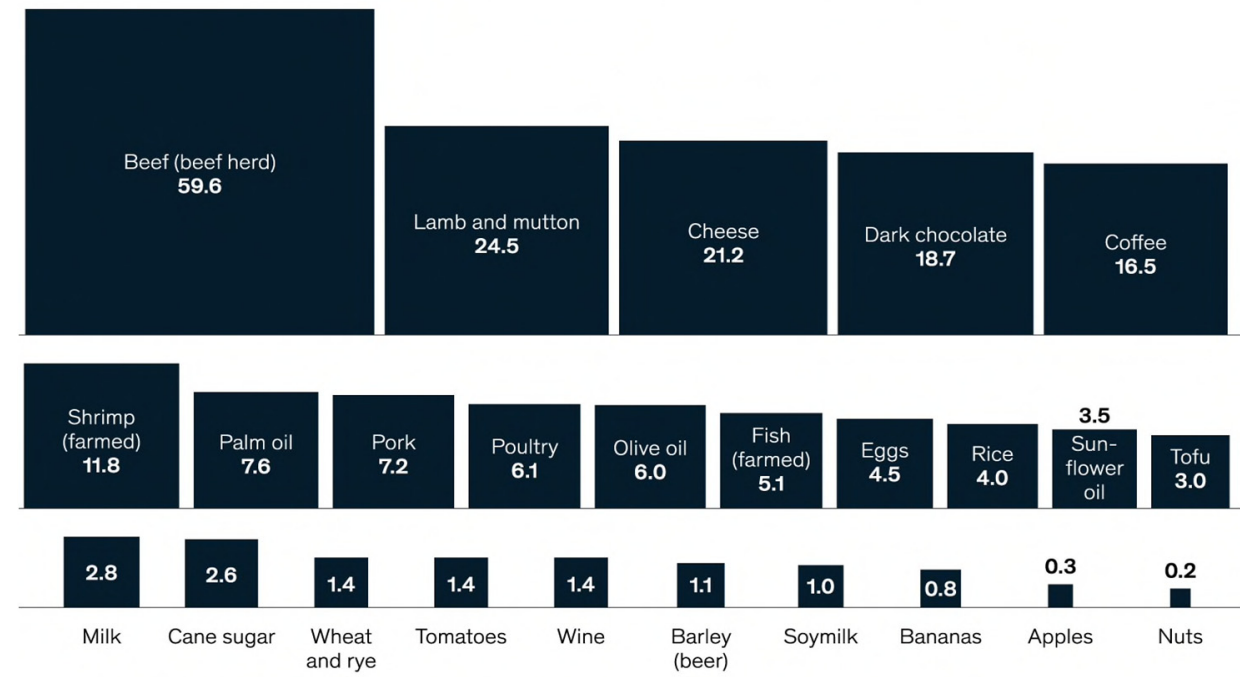

Figure 4. GHG emissions released in the environment to produce different kind of food (Reprinted with permission from Doer and Narisetti (2021). 2021 McKinsey Global Publishing [4]). 


\section{Agricultural Waste, Biobased Active Ingredients and Biopolymers}

The quantity of agrowaste derived from various supply chains and calculated at 90 million tons of oil equivalent represents an important source of starting materials, which are used in the production of pharmaceuticals, cosmetics, diet supplements, antioxidant compounds, natural fibers, biodegradable polymers and composites as well as in bio-based plastics [42-46]. Horticulture, in fact, is one of the industries with the highest production covering around $38 \%$ of the global agricultural production, $65 \%$ of which is represented from vegetables and fruits, including tomato, onion, grapes, orange, potato, wheat etc. Consequently this Industrial field, generates food loss and waste such as orange and lemon peels, grapes and olive oil pomaces, sugarcane bagasse, wheat straw among others, all coming from specific processes such as pulping, peeling, straining, and branching [47]. Additionally this waste not only increases the deterioration of the Environment, but also contributes to the scarcity of resources, loosing the opportunity to contribute to the feeding of a growing world population [47]. However, the agricultural waste has to be considered a primary source of starting materials to produce active ingredients for cosmetic and pharmaceutical use as well as polysaccharides used as essential precursors for developing biodegradable plastic-materials for sustainable packagings [48]. In any way It is to underline the biodegradable polymers for commercial application have to be based for its physical property of high tensile strength and yield [48]. In any way, the production of both active ingredients and bio-based polymers from agro-wastes is influenced by the availability of starting materials/precursors that should be cheap and available in significant quantity and designed by selected fruits and vegetables [49-53]. However, the search of green formulations for the production and packaging of Eco-friendly products, including cosmetics, diet supplement and medical devices, is mandatory in the field of green chemistry and economical sciences [49]. It is therefore necessary to try to reduce/eliminate the food losses and waste produced and generated each year. It's, in fact, to underline the food lost is estimated to be around $198.9 \mathrm{~kg}$ per capita in developed countries as the United States, where it accounts for the $40 \%$ of the whole food local production chain, while in Europe it represents 6\% only [45-54]. But it is also to remember that among the leading economies India and China have the capacity to lead the production of fruit and vegetable-based biopolymer, given the high production capacity and shear of their total global production [55]. Thus, the majority of natural actives used in cosmetic and nutraceutical formulations are currently imported from Europe were the consumers like to return to natural products. Regarding the biotechnologies used to extract an characterize the million tons of food waste it is also to remember the utilization of the microorganisms which, cultured under different nutrient and environmental conditions, are frequently used to produce biodegradable polymers by the electrospinning technique and through the fermentation of carbohydrates obtained from agricultural by-products such as corn and wheat [52-57].

\section{Biofunctional Textiles and Nanocomposites for Medical and Cosmetic Use}

Biofunctional textiles protect against anything that may injure the naked human body, including weather, insects and noxious chemicals, but may also be used for wound healing purposes [29]. Moreover garments with their content of natural and synthetic polymers and chemicals such dyes, being all day long in direct contact with the skin, may interact with its functions, provoking allergic and sensitizing reactions [58]. Tissues, in fact are one of the causes of skin diseases, such as atopic dermatitis and psoriasis [59,60]. On the other hand, clothing represents an interactive skin barrier ensuring the thermal balance despite changes in ambient temperature and humidity, thus reducing radiant heat gain and thermal stress [61]. Skin sensory comfort, in fact is determined by the direct contact of textile with the skin so that garments have to possess heat insulation and moisture balance, resistance to water vapor permeability, perspiration transport and dying time, all characteristics which depend on fabric fibers [58-61].Thus by the electrospinning technology and the use of natural polymers such a as polysaccharides it is possible to produce non-woven 
tissues characterized by an high specific surface area(up to $1000 \mathrm{~m}$ square/g), tunable porosity and mechanical resistance [62]. Various natural polymers, in fact, may be obtained from lignocellulosic fibers derived from plant waste, such as pineapple, sisal, bamboo and jute [63]. The relative fibers have interesting structural properties useful for tissue engineering and delivering of active ingredients through the skin for repairing, for example, wound healing/burns or to be used as cosmetic carriers, as reported from various studies of our research group [36-38] and better focused thereafter also. Additionally non-woven tissues, produced by different technologies, address a variety of end uses and applications so that their global consumption in 2019 has been 11.2 million tons with a growth rate valued at 5.9\% for 2014-2019 [64].

Therefore, research and innovation are based on special bioactive pharmaceutical/cosmeticemulsions and/or smart cosmeceutical-tissues capable, for example, to continually release small doses of active ingredients through the skin' intercellular or intracellular pathways for obtaining protective/moisturizing or therapeutic effects [65-71]. Moreover, tissues and clothing may impair a further antimicrobial defense, providing mechanical barrier against insect bites, mosquito and protozoa as well as has to protect from fungi, bacteria and viruses responsible for infection and allergy problems $[59,60]$. At this purpose, biocidal, antioxidant or antiinflammatory compounds may be bound to the surface of polymeric fibers for realizing specialized tissues of medical or cosmetic interest. Among the many active ingredients, silver is often used in wound dressings as a topical bactericidal agent for burns and wounds, taking always into account the right dose necessary to maintain the balance of both skin epidermal lipid barrier and microbial ecosystem [72,73]. At this purpose, our research group has verified in vitro and in vivo the activity of non-woven tissues made by specialized fibers and different natural or natural-derided polymers, such as gelatin, chitin, lignin, pullulan polylactic acid etc. Thus on the fibers' surface of $\mathrm{CN}$, for example, has been bound a low quantity (20ppm) of nano-structured silver. The obtained tissue has shown an interesting activity on burns of 1st and 2nd grade with an high antiinflammatory and a faster skin repairing effectiveness, compared to commercial advanced medications [54-78]. Probably this activity was due to the particular characteristics of the non-woven bio-tissue made by biodegradable fibers of polysaccharide nanocomposites (gelatin lignin) bound to chitin and silver ions (Ag+) at their nano dimension, having therefore an high area/weight ratio and an interesting antibacterial effectiveness (Figure 5) [78,79].The high humidity of burn, in fact, seems to promote an easy silver uptake throughout the skin that justify its interesting activity [75-81].

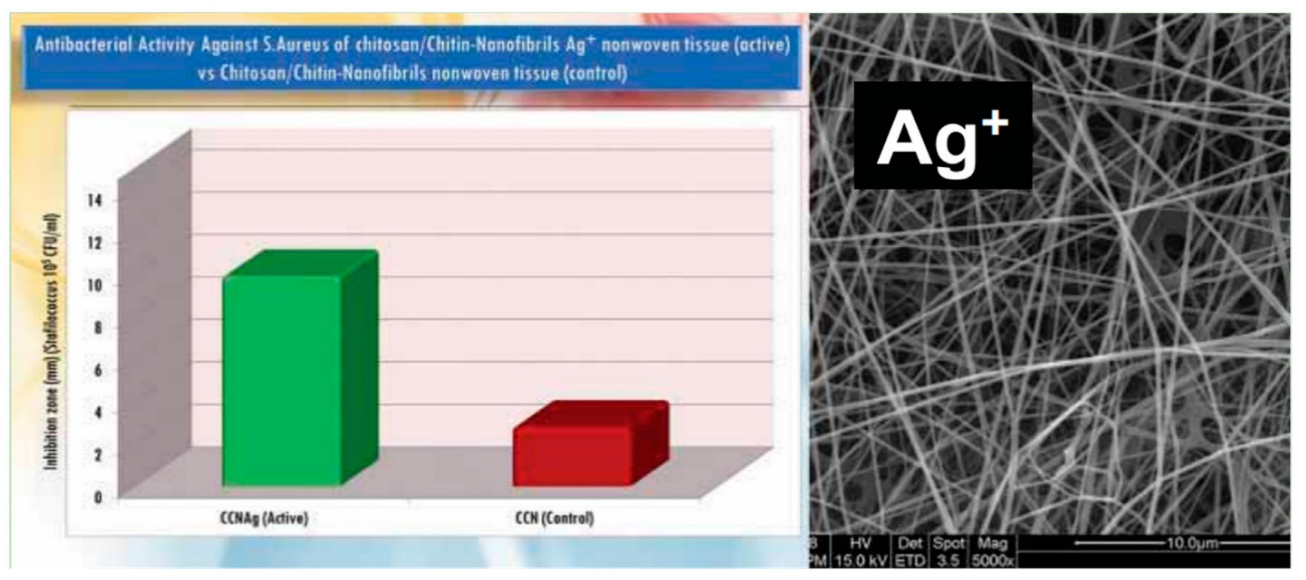

Figure 5. Antimicrobial activity of non-woven tissue made by polysaccharides and Chitin nanofibrils bound to nanosized $\mathrm{Ag}+[68]$.

Numerous are the possible natural polymers useful to make biodegradable nanocomposites and wound dressings. Among the more used to produce nanocomposites and bioactive scaffolds there are hyaluronic acid, collagen, chitin/chitosan, lignin, gelatin, 
alginic acid and keratin, because of their non-toxicity, biodegradability, biocompatibility non immunogenicity and ready availability from by-products materials, as food waste (Figure 6) [76-78]. In particular and as previously reported, eliminating food waste throughout the entire supply chain, not only saves precious resources but also avoids the harmful methane' activity [5]. Moreover, it is interesting to underline the further possibility to use these polymers for encapsulating bio-ingredients into micro-nano complexes of chitin nanofibrils-nanolignin (CN-LG). In turn these complexes, used as active agents or carriers may be embedded into biocomposite non-woven tissues with the aim to enhance the skin regenerating activity of innovative and rejuvenating anti-aging cosmeceuticals [79-84]. The tissues, in fact, are generically prepared combining multiple fibrous layers of different types of polymers, fibers or textile components to obtain structures characterized by a high surface area/weight ratio and a porosity made by an interesting pore size distribution and interconnectivity [78]. At this purpose, it is to underline that $1 \mathrm{~g}$ of chitin develops 2 square meters of tissue, while $1 \mathrm{~g}$ of chitin nanofibers $(\mathrm{CN})$ develops more than 180 square meters [85]. Additionally it is also possible to make innovative bio-nanocomposites, combining for example chitin with synthetic bio-based polymers, including polylactic acid (PLA) [86,87] or Polyhydroxyalkanoates (PHA) [88] to improve their mechanical properties. Thus, the incorporation of just $1 \%$ of chitin into PLA resulted useful to enhance the mechanical properties of nanocomposites as well as to increase their viscosity and the anti adhesive and antifungal activity [87]. Bio-nanocomposites, in fact, show to be material possessing markedly improved properties when compared with pure polymers or conventional composites. However, the nanocomposite performance depends on various nanoparticles features, including size, high surface area/weight ratio, compatibility with matrix and dispersion [89]. Therefore chitin, when used at nano dimension, encourages the skin regeneration activity probably because its nanofibrils provide a three-dimensional structure that mimics the natural extracellular matrix (ECM) (Figure 7) [90]. Moreover and first of all, the different polymers and active ingredients have to be well selected, according to their therapeutic or cosmetic applications (Figure 8) [91,92]. Just as an example, our research group has encapsulated glycyrrhetinic acid (GA) as antiinflammatory agent and vitamin $\mathrm{E}$ as antioxidant compound into the complex chitin nanofibrils and nanolignin (CN-LG), verifying their distribution on the novel textile surface and the Vit E recovery (Figure 9) [93,94]. The effectiveness of the final tissue obtained by the use of the complex CN-LG-GA has been evaluated both in vitro and in vivo [93-95]. Naturally both polymers and active ingredients used have been obtained from food waste.These and other studies in progress are considered fundamental for recovering new active compound and innovative natural carriers necessary to maintain the Earth' raw materials for the future generations and save the environmental balance.

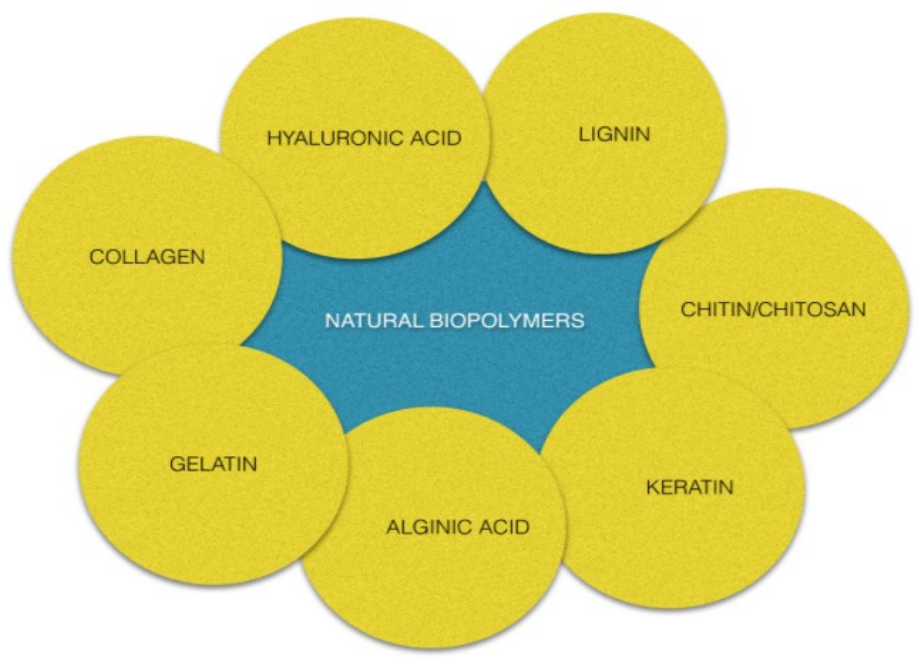

Figure 6. Some of the natural polymers used to make Nanocomposites and wound dressings. 

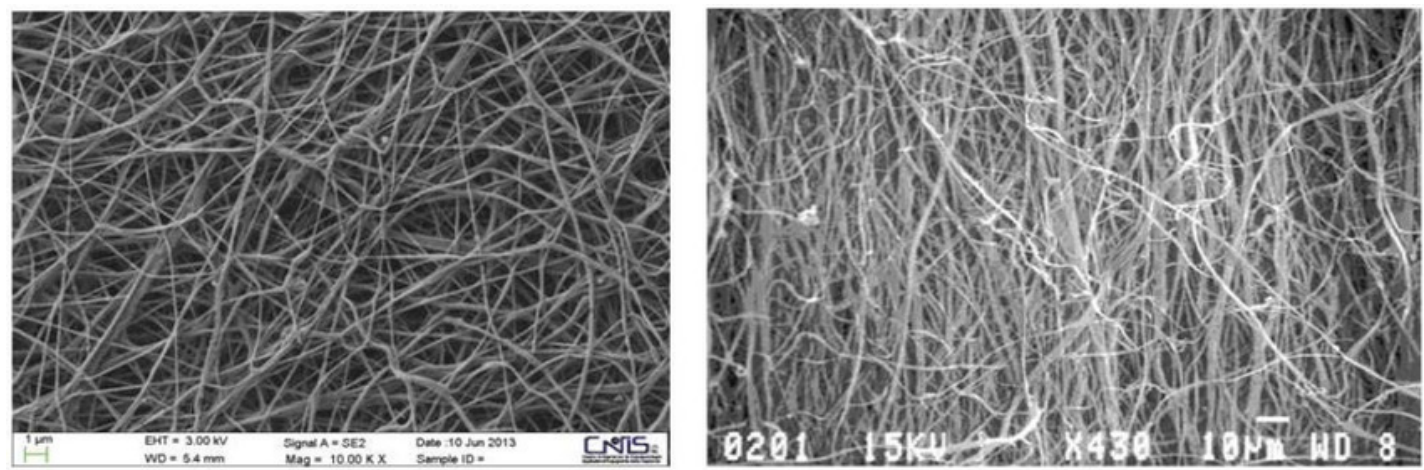

Figure 7. Structure of chitin-made tissue (left) compared to the Natural ExtracellulaMatrix (ECM (right). By Scanning Electron Microscopy (SEM) (Reprinted with permission from Donnarumma et al. (2019). 2019. MDPI [89]).

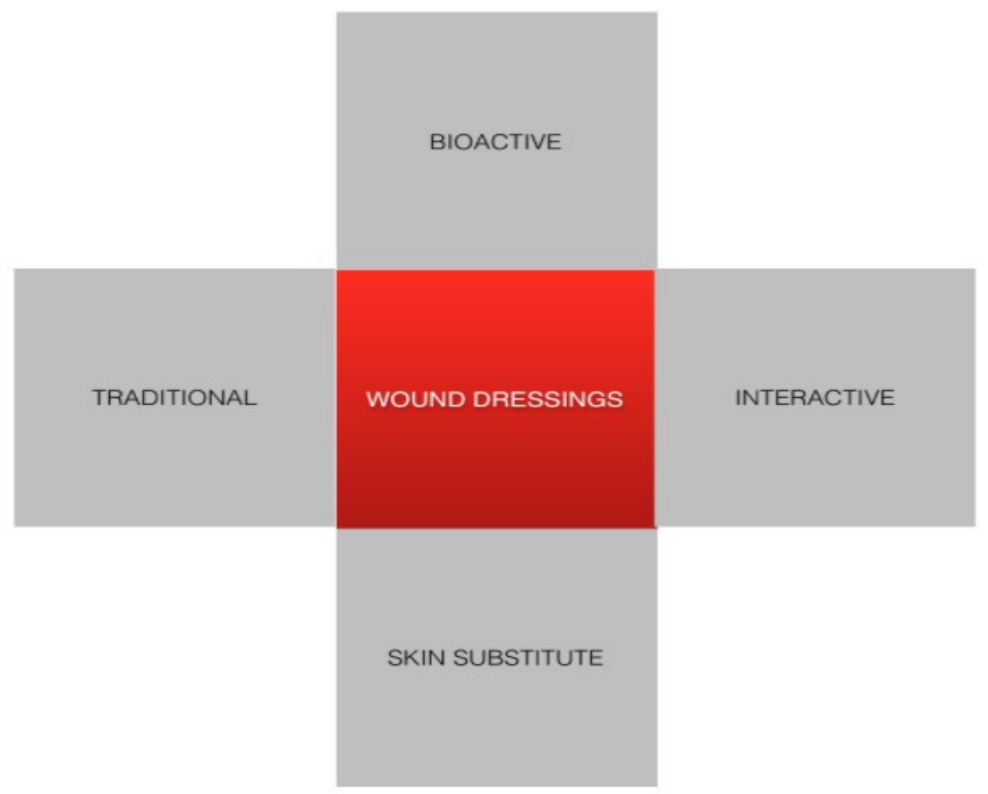

Figure 8. Classification of wound dressings according to their applications.

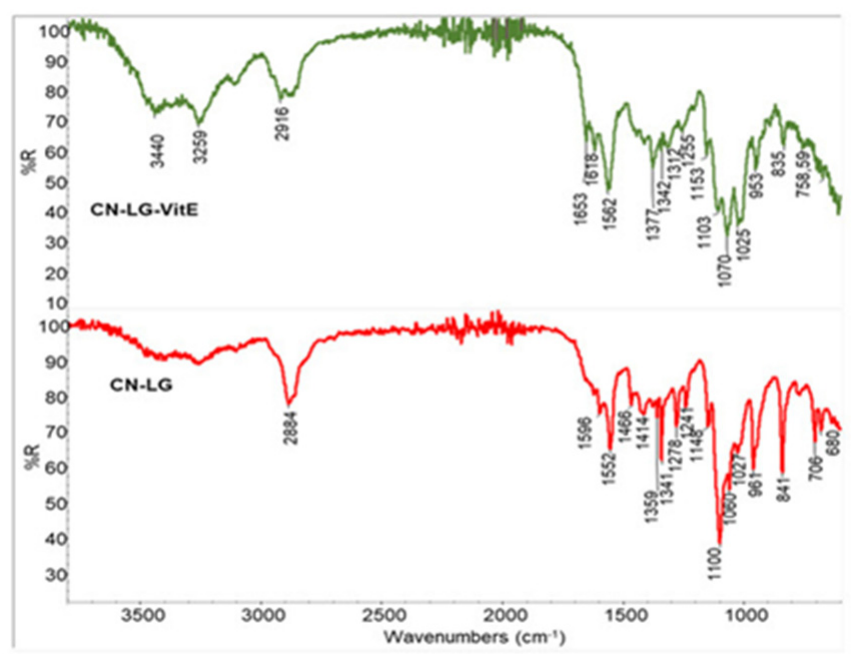

Figure 9. Infrared spectrum of the complexes CN-LG and CN-LG-VitE (Reprinted with permission from Panariello et al. (2021) MDPI [93]). 


\section{Conclusions}

Using the actual food waste and establishing the circular economy to make biodegradable and natural-based products and packaging materials, will give the industry a business calculated around USD 7.7 trillion by 2030 [95]. Just as an example, the global Cosmetic Industry, evaluated USD 483 billion in 2020 and estimated to range USD 784.6 billion by 2025 (Figure 10) [96] could produce around USD 37 billion of non biodegradable primary packaging. In this market the global organic and natural cosmetics are expected to reach USD 25.11 billion by 2014 for the consumer's request who are looking for products made by renewable biobased ingredients preferred because considered non toxic and biodegradable [96]. Moreover the current market for sustainable, natural and green products is massive because additionally, government support are creating a favorable climate for big business players. Therefore, the chemical composition of the ingredients and their doses in the formulation decides the potential impact on health of the cosmetic product to be purchased [97]. It is, in fact, to underline the every day use and continuous exposition of humans to a wide range of different kind of chemicals derived from several sources, including cosmetics that may cause the so called "cocktail effect", due, for example, to a synergistic interaction of the same ingredients used by different products, as fragrances $[97,98]$. However, beauty cosmetics are the fastest-growing market worldwide not only for women but also for male consumers because after pandemic they feel more confident about their look than a year ago [99]. Thus 34\% of males showed more interest in beauty/cosmetics buying them in an unprecedented rate in early 2020 in all the markets from China to Australia, North America and Europe, just as women interest showed early signs of stagnation $[99,100]$. Consequently, products that improve or maintain appearance seem now just important as ones that enhance it, so that people spent billions to look good and healthy during the lockdown periods! Consumers, in fact, are looking for more from the life in the past-pandemic world, and wellbeing is talking center stage to live to the fullest [101]. On the other hand, the worldwide citizens are becoming to understand the need to change their daily habits, counteracting waste at home. However, governments and consumers have finally recognized that global warming, waste disposal, air pollution and natural resources exhaustion are the main cause of many environmental disasters [102-104]. For all these reasons, food Industry has increased research studies by a manufacturer consumer-oriented approach with the aim to optimize the food-chain production and utilize its waste for obtaining active ingredients to be used for producing not only functional food but also advanced medications, diet supplements and natural cosmetics, involving in this new business other industrial sectors of developing countries also $[105,106]$. Thus the need to maintain and protect the authenticity of the traditional products valorizing the food processes by sustainable solutions that, balancing the energy and water consumption, may represent a responsible utilization of the natural resources with a respect for the environment [107-109]. Consequently, the studies for obtaining new pure and active bio-ingredients environmentally-friendly by the use of biochemical and enzymatic technologies are progressing day by day, as well as to treat appropriately the industrial food by-products valorizing its precious content [110-114]. Continuing to invest in research and innovation to stop the food losses and turning waste into valuable products, it will be possible to increase the profitability of food, pharmaceutical and cosmetic industries, ensuring an healthy environment in addition to a sustainable development for all [113]. According to United Nations, in fact, the sustainable development is defined as "the development that meets the needs of the present without compromising the ability of future generations to meet their own needs" [115]. Therefore, the industry needs to increase its knowledge and technical know-how ameliorating the producing methodologies and utilizing the biomolecules' content of the releasing by-products adopting the circular economy approach [116]. Thus changing the way of producing, consuming and living, it will be possible to deliver a zero-plastic pollution and waste, reducing carbon emissions and helping to boost and drive a circular bio-economy capable to safeguard the environment and combat the climate change [117-123]. Circular bio-economy, in fact, based on 
nature-based goods, recycling materials and investments in green initiatives by the power of bioscience and biotechnology, might represent a solution to address the resources scarcity and help to tackle the air and marine pollution [118-122]. Thus consumers education together with industry research and innovation represent the key to transitioning from a plastic-based economy to a bio-based ones, by changing the production of feedstock and non recyclable petrol-based materials in favor of degradable fossil-free goods, medical devices and cosmetics [124-127]. For all these reasons, the food and cosmetic industry are becoming to pay attention to these problems by the research of natural sources of active ingredients that, extracted from food waste by the available sustainable technologies, may be used for producing biodegradable packagings and innovative products skin- and environmentally-friendly, fundamental to reduce the by-products' negative environmental impact [125-138]. Moreover, the industries are changing the non biodegradable packaging materials, knowing, for example, that $95 \%$ of beauty packaging is thrown out after just one use, and only $14 \%$ of plastic makes it to a recycling center [18-21]. Unfortunately today only $9 \%$ of all plastic waste ever produced has been recycled, about $12 \%$ incinerated and 79\% ended up in landfills [18-21,139]. Therefore, adopting a virtuous industrial comportment, it will possible not only to use the actual food waste safeguarding the environment, but also to increase the global food production, necessary to eliminate the actual worldwide hunger and poverty [122-124]. Recycling food industrial waste should not be an option rather an obligation that call for serious attention to finally achieve a circular economy [116,139]. By the actual molecular biology and biotechnology it seems possible, in fact, to obtain a sustainable development of agricultural practices as well as of food processing, improving among others production and availability of biodegradable and effective medical devices, diet supplements and cosmetics to range an healthy beauty in a clean environment. The proposed production of smart cosmeceutical-tissues packed by nature-derived materials seem to go in the right direction because made by biodegradable and natural polymers, including chitin and lignin, obtained by food byproducts through a sustainable technology at zero waste [38,39,80,124-128]. Moreover, as reported previously these innovative products don't contain preservatives, emulsifiers, fragrances and other chemical compounds often cause of allergic and/or sensitizing problems [18,58-60]. In conclusion, it is necessary to stop the planet global warming, restore biodiversity and protect lands and oceans, building an ecosystem that really enables the truly circularity of biomaterials and economy for all. Thus the urgent need to develop new value chains, and innovative technologies and infrastructures capable to create a future comfortable and green planet for the future generations.

So doing people of all countries could obtain wellbeing and sufficient money, living in more green cities consuming biodegradable and safe food produced by a circular bioeconomy, using healthy fashion, cosmetics and goods to live in a more equal world [140-147]. 


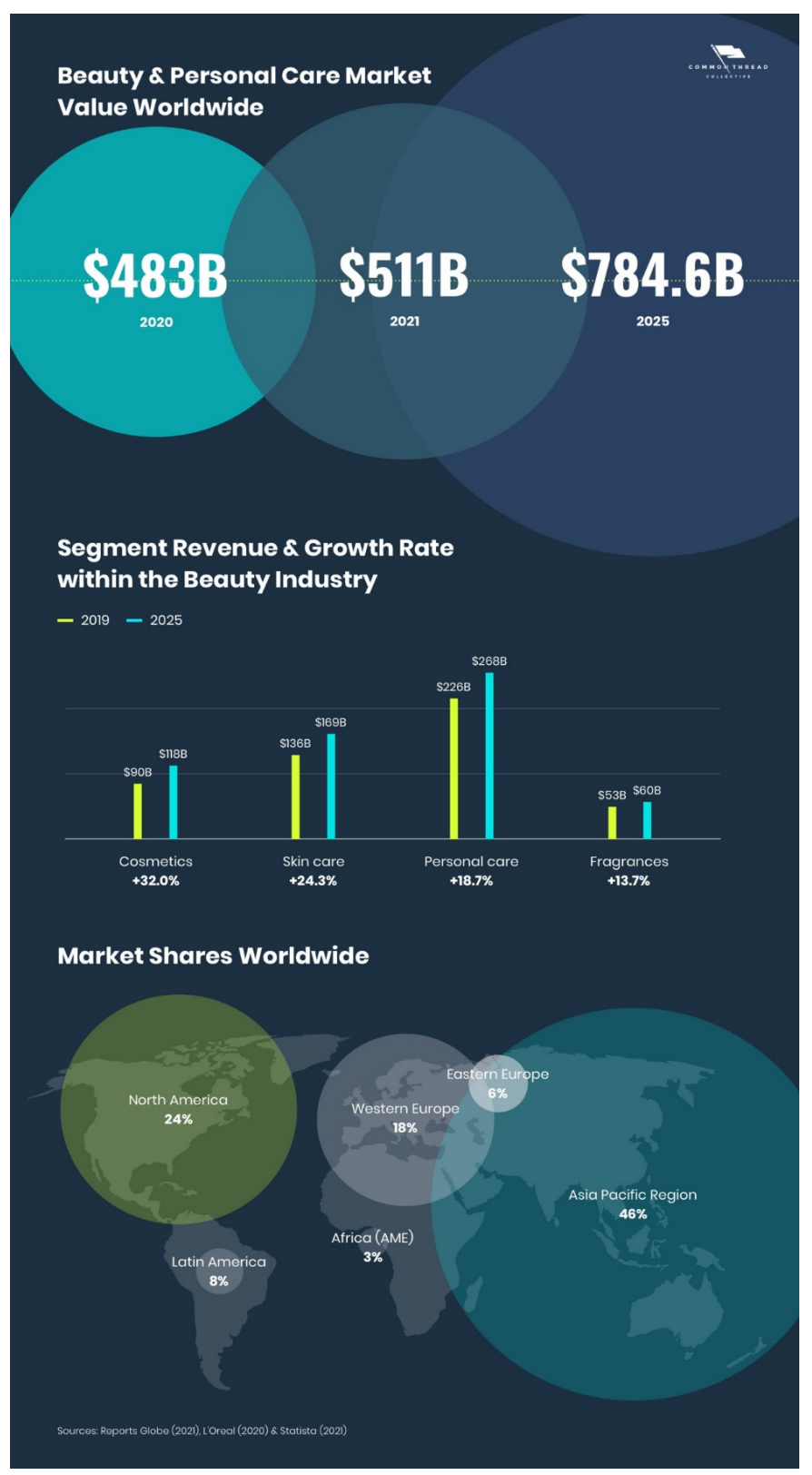

Figure 10. Beauty Industry Trends 2020-2025 (Reprinted with permission from Common Thread (2021) [96]).

Author Contributions: Idea of manuscript P.M.; writing-original draft preparation P.M., G.M.; writing review and editing P.M., X.G., N.V., A.G., A.L., G.M.; supervision P.M., X.G.; All authors have read and agreed to the published version of the manuscript.

Funding: This research received no external funding.

Institutional Review Board Statement: Not applicable.

Informed Consent Statement: Not applicable.

Data Availability Statement: Not applicable.

Conflicts of Interest: The authors declare no conflict of interest. 


\section{References}

1. FAO. Food Security and Nutrition around the World in 2020; Food and Agriculture Organization of the United Nations: Rome, Italy, 2021.

2. UNEP, Food Waste Index Report Programme, 2020; Union Nations Environment Programme: New York, NY, USA., 2020.

3. de Cleene, S.; Bora, S. World Economic Forum Incentivating Food Systems Transformation-Report, 2020. Available online: https:/ / www.weforum.org/reports/incentivizing-food-systems-transformation (accessed on 14 November 2021).

4. Doerr, J.; Narisetti, R. (Eds.) Speed E Scale: An Action Plan for Solving our Climate Crisis Now; McKinsey Global Publishing: Minato City, Tokyo, 2021; Available online: www.mackinseyandcompany.com (accessed on 14 November 2021).

5. De Fabrizio, S.; Glazener, W.; Hart, C.; Henderson, K.; Kar, J.; Katz, J. Combining Methane Emissions: How Five Industries Can Counter a Major Climate Threat, 2021, McKinsey\&Company Sustainability Report. Available online: www.mckinseyandcompany. com (accessed on 14 November 2021).

6. FAO. Food Wastage Footprint E Climate Change, 2021; Food and Agriculture Organization of the United Nations: Rome, Italy, 2021.

7. Ivanova, D.; Barret, J.; Wiedenhofer, D.; Macura, B.; Callaghan, M.; Creuzzig, F. Quantifying the Potential for Climate Change Mitigation of Consumption Options. Envir. Res. Lett. 2020, 15, 093001. [CrossRef]

8. Unsalan, E. Food in the Circular Economy. Ellen McArthur Foundation, 2019. Available online: https://archive. ellenmacarthurfoundation.org/explore/food-cities-the-circular-economy (accessed on 30 December 2021).

9. EC. Recycling Z FOOD Packaging \& Food Waste in Plastic Revolution 2020; European Economic and Social Committee: Bruxelles, Belgium, 2021.

10. Klevnas, P.; Kulldorff, H.; Enkvist, R.A. The Circular Economu and COVID-19 Recovery. Ellen McArthur Foundation Study. Available online: https:/ / ellenmacarthurfoundation.org/a-transformative-covid-19-recovery-strategy (accessed on 30 December 2021).

11. Avionics, C.H.; Gorbi, S.; Regoli, F. Plastics and Microplastics in the Oceans: From Emerging Pollutants to Emerged Threat. Mar. Environ. Res. 2017, 128, 2-11.

12. TOC. The Great Pacific Garbage Patch, 2021, The Ocean Cleanup Report. Available online: https://theoceancleanup.com/greatpacific-garbage-patch/ (accessed on 16 November 2021).

13. Leslie, H.A. Plastic in Cosmetics, United Nations Environment Programme (UNEP) Report 2015. Available online: https://wedocs unep.org/handle/20.500.11822/21754;jsessionid=32576510FBF1A006D01A500883279EFC (accessed on 27 December 2021).

14. Cheung, P.K.; Fok, L. Characterisation of plastic microbeads in facial scrubs and their estimated emissions in Mainland China. Water Res. 2017, 122, 53-61. [CrossRef] [PubMed]

15. Lei, K.; Qi, I.; Ho, F.; Liu, Q.; Wei, Z.; Qi, H.; Cui, S. Microplastics releasing from personal care and cosmetic products in China. Mar. Pollut. Bull. 2017, 123, 122-126. [CrossRef]

16. Sun, Q.; Ren, S.Y.; Ni, H.G. Incidence of microplastics in personal care products: An appreciable part of plastic pollution. Sci. Total Environ. 2020, 742, 140218. [CrossRef]

17. Aagnostic, L.; Varvaresou, A.; Protopapa, E.; Carayanni, P. Worldwide actions against plastic pollution from microbeads and microplastics in cosmetics focusing on European policies. Has the issue been handled effectively? Mar. Pollut. Bull. 2021, 162, 111883. [CrossRef]

18. Bashir, S.M.; Kimiko, S.; Mak, C.-W.; Fang, J.K.-H.; Goncalves, D. Personal Care and Cosmetic Products as a Potential Source of Environmental Contamination by Microplastics in a Densely Populated Asian City. Front. Mar. Sci. 2021, 8, 604. [CrossRef]

19. Meaza, I.; Toyoda, S.H.; Wise, J.P. Microplastics in Sea, Turtles, Marine mammals and Humans: A one Environmental Health Perspective. Front. Environ. Sci. 2021, 8, 575614. [CrossRef]

20. DFO. Plastic Food Web, 2021 Debris Free Oceans. Available online: www.debrisfreeoceans.org (accessed on 16 November 2021)

21. Hermabessiere, L.; Dehaut, A.; Pauz-Pont, I.; Lacroix, C.; Jezequel, J.; Soudant, P.; Duflos, G. Occurrence and Effects of Plastic Additives on Marine Environment and Organisms. Chemosphere 2017, 182, 781-793. [CrossRef]

22. Hernandez, L.M.; Xu, E.G.; Larsson, H.C.E.; Tahara, R.; Mhisura, V.B.; Tufenkji, N. Plastic Teabags release Billions of microparticles and nanoparticles into tea. Environ. Sci. Technol. 2019, 53, 12300-12310. [CrossRef]

23. Ragusa, A.; Svelato, A.; Santacroce, C.; Catalano, P.; Notarstefano, V.; Carnevali, O. Plasticenta: First Evidence of Microplastics in Human Placenta. Environ. Int. 2021, 146, 106274. [CrossRef] [PubMed]

24. Morganti, P.; Vukovic, N.; Morganti, G.; Chen, H.-D. Green Cities, Welbeing and Aging. In Biofunctional Textiles for an Aging Skin. From Bench to the Market; Morganti, P., Ed.; Lambert Academic Publishing: Chisinau, Moldova, 2021.

25. Baiano, A. Recovery of Biomolecules from Food Waste-A Review. Molecules 2014, 19, 14821-14842. [CrossRef] [PubMed]

26. Liu, J.; Qi, J.; Luo, J.; Qin, W.; Luo, Q.; Zhang, Q. Okra in Food Field: Nutritional Value, Health Benefits and Effects Processing Methods in Quality. Food Rev. Inter. 2021, 37, 67-90. [CrossRef]

27. Saater, C.; Ruiz, L.; Delgado, S.; Ruas-Madiedo, P.; Margolles, A. Valorization of Vegetable Food Waste and by-products Through Fermentation Processes. Front. Microbiol. 2020, 11, 2604. [CrossRef]

28. Dewanjee, S.; Bhattacharjee, N.; Chakraborty, P.; Bhattacharjee, S. Carotenoids as Antioxidant Agents. In Carotenoids: Structure and Function in Human Body; Zia-ul-Haq, M., Idewanyee, S., Riaz, M., Eds.; Springer Nature: Cham, Switzerland, 2021 ; pp. $447-474$.

29. Bacakova, L.; Pajorova, J.; Zikmundova, M.; Fiolva, E.; Mikes, P.; Jenova, V. Tissue fibrous Scaffolds for Skin Tissue Engineering and Wound Healing Based on Nature-Derived Polymers. In current and Future Aspect of Nanomedicine; Khalil, I., Ed.; IntechOpen: London, UK, 2020; p. 893. [CrossRef] 
30. Berra, B.; Zoppi, S.; Rapelli, S. Vitamins and Minerals as Skin Nutrients. In Every Day Problems in Dermatology: The Cosmetic Connection; Morganti, P., Ebling, F.J.G., Eds.; International Ediemme: Rome, Italy, 1990; pp. 279-289. ISSN 0393-5779.

31. Nunes, M.A.; Costa, A.S.G.; Bessada, S.; Santos, J.; Puga, H.; Alves, R.C. Olive pomace as a valuable source of Bioactive compounds. A study regarding its lipid and water-soluble components. Sci. Total Environ. 2018, 644, 229-236. [CrossRef]

32. Miranda, I.; Simoes, R.; Medeiras, B.; Nampoothiri, K.M.; Sukumaran, R.K.; Rajan, D. Valorization of lignocellulosic residues from the olive oil Industry by production of lignans, glucose and functional sugars. Biosesour. Technol. 2019, 292, 121936. [CrossRef]

33. Hoss, I.; Rajha, H.N.; Elkioury, R.; Youssef, S.; Manca, M.L.; Manconi, M. Valorization of Wine-making by-Products Extracts in Cosmetics. Cosmetics 2021, 8, 109. [CrossRef]

34. Hong, T.H.; Moon, J.-Y.; Lee, Y.-C. Natural Antioxidants from Plant Extracts in Skincare Cosmetics: Recent Applications Challenges and Persoectives. Cosmetics 2021, 8, 106. [CrossRef]

35. Dinner, M.; Radic, I. Innovative Circular Business models in the Olive OIL Sector for Sustanable Mediterranean Agrifood Systems Sustainability 2021, 13, 2588. [CrossRef]

36. Coltelli, M.B.; Danti, S.; De Ceerck, K.; Lazzeri, S.; Morganti, P. Pullulan for Advanced Sustainable Body-and Skin-Contact Applications. J. Funct. Biomater. 2020, 11, 20. [CrossRef]

37. Danti, S.; Trombi, L.; Fusco, A.; Azimi, B.; Lazzeri, A.; Morganti, P. Chitin Nanofibrils and Nanolignin as Functional Agents in Skin Regeneration. Int. J. Mol. Sci. 2019, 20, 2669. [CrossRef] [PubMed]

38. Morganti, P.; Coltelli, M.B. A New Carrier for Advanced Cosmeceuticals. Cosmetics 2019, 6, 10. [CrossRef]

39. Morganti, P. Chitin Nanofibrils and their Derivatives as Cosmeceuticals. In Chitin, Chitosan, Oligosaccharudes and Their Derivatives; Kim, S.-K., Ed.; CRC Press: Boca Raton, FL, USA, 2011; pp. 531-541.

40. Morganti, P.; Tishchenko, G.; Palombo, M.; Kelnar, I.; Brozova, L.; Spirkova, M. Chitin Nanofibril for Biomometic Products: Nanoparticles and Nanocomosite Chitosan Films in Health Care. In Marine Biomaterials: Characterization, Isolation and Application; Kim, S.-K., Ed.; CRC Press: Boca Raton, FL, USA, 2013; pp. 681-715.

41. Morganti, P.; Carezzi, F.; Del Ciotto, P.; Morganti, G.; Nunziata, M.L.; Gao, X. Chitin Nanofibrils: A natural multifunctional polymer. In Nanobiotechnology; Phonix, D.A., Ahmed, W., Eds.; One Central Press: Manchester, UK, 2014; pp. 1-31.

42. Xie, Y.; Niu, X.; Yang, J. Active biodegradable films based on whole potato peel incorporated with bacterial cellulose and Curcumin. Int. J. Biol. Macromol. 2020, 150, 480-491. [CrossRef] [PubMed]

43. Maraveas, C. Production of sustainable and biodegradable polymers from agriculture waste. Polymers 2020, 12, 1127. [CrossRef]

44. Fenollar, O.; Balart, R.; Fortunati, E. Characterization and enzymatic degradation study of poly (e-caprolactone)-based biocomposites from almond agriculturals. Polym. Degrad. Stab. 2016, 132, 181-190.

45. Vroman, I.; Tighzert, L. Biodegradable polymers. Materials 2009, 207, 309-344. [CrossRef]

46. Ziolkowska, J.R. Economic and Environmental Costs of Agricultural Losses and Waste in the US. Int. J. Food Eng. 2017, 3, 140-145. [CrossRef]

47. Jimenez-Moreno, N.; Esparza, I.; Bimbela, F.; Gandia, L.M.; Ancin-Azpicueta, C. Valorization of selected fruit and vegetable wastes as bioactive compounds: Opportunities and challenges. Crit. Rev. Environ. Sci. Technol. 2020, 50, 2061-2108. [CrossRef]

48. Di Donato, P.; Taurisano, V.; Poli, A. Vegetable wastes derived polysaccharides as natural Eco-friendly plasticizers of sodium alginate. Carbohydr. Polym. 2020, 229, 115427. [CrossRef]

49. Barbulova, A.; Colucci, G.; Apone, F. New Trends in Cosmetics: By-Products of Plant Origin and Potential use as Cosmetic Native Ingredient. Cosmetics 2015, 2, 82-92. [CrossRef]

50. Spares, R.M.D.; Siqueira, N.M.; Prabhakaranan, M.P. Electrospinning and Electrisoray of Biobased and Natural Polymers fir Biomaterials Developent. Mater. Sci. Eng. C 2018, 92, 969-982.

51. Latos-Brozio, M.; Masek, A. Biodegradable Polyester Materials Containing Gallates. Polymers 2020, 12, 677. [CrossRef] [PubMed]

52. Bashir, A.; Jabeen, S.; Gull, N.; Islam, A.; Sultan, M. Macromolecules co-concentration Effect of silane with natural extract in biodegradable polymers films for food packaging. Int. J. Biol. Macromol. 2018, 106, 351-359. [CrossRef]

53. Renata, S.; Ferreira, C.; Reinert, O.; Gandolfi, R.; Brito, L.; Ilhe, C. Characterization and starch-based bioplastics from jackfruit seed plasticized with glycerol. J. Food Sci. Technol. 2018, 55, 278-286.

54. Nunez, K.A.; Silva, M.L.S.; Jerber, J.Z.; Kalid, R.D.A. Waste green coconut shells: Diagnosis of the disposal and application for use in other products. J. Clean. Prod. 2020, 255, 120169. [CrossRef]

55. Sherma, P.; Gaur, V.K.; Kim, S.; Pandey, A. Microbial strategies for bio-transforming food waste into resources. Bioresour. Technol. 2020, 299, 122580. [CrossRef] [PubMed]

56. Luengo, J.M.; Garcia, B.; Sandoval, A.; Naharro, G.; Oliveira, E.R. Bioplastics from microorganisms. Curr. Opin. Microbiol. 2003, 6, 251-260. [CrossRef]

57. Duenas, M.; Garcia-Estevez, I. Agricultural and Food Waste: Analysis, Characterization and Extracting of Bioactive Compounds and their Possible Utilization. Foods 2020, 9, 817. [CrossRef]

58. Van Der Puttle, I.; Qi, S.; Affoutit, F.; de Wolf, K.; Devaere, S.; Albrecht, E. Study on the link between allergic reactions and chemicals in the textile products. In European Commission WRM11.8088-Final Report (Draft No 7); RPS Advise: Delft, The Netherlands, 2013.

59. Diepgen, T.K.; Stabler, A.; Hornstein, O.P. Textile in tolerance in atopic eczema-A Controlled Clinical study. Z. Hautkr. 1990, 65, 907-910. 
60. Williams, J.R.; Burr, M.L.; Williams, H.C. Factor influencing Atopic Dermatitis-A question aire surgery of school children's perceptions. Br. J. Dermatol. 2004, 150, 1154-1161. [CrossRef]

61. Woolina, U.; Abdel-Naser, M.B.; Verma, S. Skin Physiology and Textiles- Considerations of Basic Interactions, 2006. In Biofunctional Textikes and the Skin; Hipler, U., Elsner, P., Eds.; Karger: Basel, Switzerland, 2006; pp. 1-16.

62. Sill, T.J.; von Recum, H.A. Electrospinning: Applications in drug delivery and tissue engineering. Biomaterials 2008, 29, 1989-2006. [CrossRef] [PubMed]

63. Satyanarayana, K.G.; Arizaga, G.G.C.; Wypych, F. Biodegradable composites based on lignocellulosic fibers-An Overview. Prog. Polym. Sci. 2009, 34, 982-1021. [CrossRef]

64. Sabra, S.; Raab, D.M.; Agwad, M.M.; Rohami, S. Recent Advances in electrospun nanofibers for some biomedical applications Eur. J. Pharm. Sci. 2020, 144, 105224. [CrossRef] [PubMed]

65. Morganti, P.; Ruocco, E.; Wolf, R.; Ruocco, V. Percutaneous absorption and delivery systems. Clin. Dermatol. 2001, 19, 489-501. [CrossRef]

66. Morganti, P.; Cardillo, A. Delivery system affect the efficacy of cosmetics. Eurocosmetics 2002, 10, 24-26.

67. Biagini, G.; Zizzi, A.; Giantomassi, F.; Orlandi, F.; Lucarini, L. Cutaneous absorption of nanostructured chitin associated with natural synergistic molecules (Lutein). J. Appl. Cosmetol. 2008, 26, 69-80.

68. Tishchenko, G.; Morganti, P.; Stoller, M.; Kelnar, I.; Mikesova, J.; Kovariva, J. Chitin Nanofibril-chitosan composite films: Characteization and properties. In Bionanotechnology to Save the Environment; Morganti, P., Ed.; MDPI: Basel, Switzerland, 2019; pp. 191-226.

69. Morganti, P.; Chen, H.-D.; Morganti, G. Nanocosmetics: Future Perspective 2020. In Nanocosmetics: Fundamentaks, Applcstions and Toxicity; Nanda, A., Nanda, S., Nguyen, T.A., Rajendran, S., Slimani, Y., Eds.; Elsevier: Amsterdam, The Netherlands, 2020; pp. 455-481.

70. Pavlov, P.; Siamidi, A.; Varvaresou, A.; Vlachou, M. Skin care formulations and lipid careers as skin moisturizing agents. Cosmetics 2021, 8, 89. [CrossRef]

71. Morganti, P.; Morganti, G.; Yudin, V.E.; Chen, H.-D. Chitin \& Lignin: Old polymers and New Tissue-carriers. Dermatol. Dermat. 2021, 6, 1-11. [CrossRef]

72. Elias, P.M. Epidermal lipids, barrier function, and desquamation. J. Invesigt. Dermatol. 1993, 80, 44S-49S. [CrossRef]

73. Byrd, A.L.; Belkaid, Y.; Segreteria, J.A. The Human Skin Microbiome. Nat. Rev. Microb. 2018, 16, 143-155. [CrossRef]

74. Donnarumma, G.; Fusco, A.; Morganti, P.; Palombo, M.; Anniboletti, T.; Del Ciotto, P. Advanced Medications Made by Green Nanocomposites. Int. J. Res. Nano Sci. 2018, 5, 261-270.

75. Morganti, P.; Fusco, A.; Paoletti, I.; Perfetto, B.; Del Ciotto, P.; Palombo, M.; Chianese, A.; Baroni, A.; Donnarumma, G. Antiinflammatory, Immunomodulatory and Tissue Repair Activity on Human Keratinocytes by Green Innovative Nanocomposites. Materials 2017, 10, 843. [CrossRef] [PubMed]

76. Anniboletti, T.; Palombo, M.; Moroni, S.; Bruno, S.; Palombo, P.; Morganti, P. Clinical Activity of Innovative Polymeric Nanopaticls an Non-woven Tissues 2019. In Bioeconomy and Bionanotechnology to Save the Environment; Morganti, P., Ed.; MDPI: Basel, Switzerland, 2019; pp. 340-360.

77. Allen, S.; Aderibigbe, B.A. Hyaluronic Acid-based Scaffolds as Potential Bioactive Wound Dressings. Polimers 2021, 13, 2102. [CrossRef]

78. Morganti, P.; Palombo, M.; Fabrizi, G.; Guarneri, F.; Slovacchia, F.; Cardillo, A. New Insight on Antiaging Activity of ChitinNanofibril-Hyaluronan Block Copolymers Entrapping Active Ingredients: In vitro and in vivo study. J. Appl. Cosmetol. 2013, 41, 1-29.

79. Dai, T.; Huang, Y.-Y.; Sharma, S.K.; Hashmi, J.T.; Kurup, D.B.; Hamblim, M.R. Topical antimicrobial for burn wound infections. Recent Pat. Anti-Infect Drug Discov. 2010, 5, 124-151. [CrossRef] [PubMed]

80. Morganti, P.; Danti, S.; Coltelli, M.B. Chitin and Lignin to produce Biocompatible Tissues. Res. Clin. Dermatol. 2018, 1, 5-11. [CrossRef]

81. Palombo, M. Innovative Solutions for Advanced Medications:Biochemical and Clinical Data. In Proceeding of the 11th ISCD International Congress of Cosmetic Dermatology, Beijing, China, 26-28 September 2014; p. 38.

82. Morganti, P.; Chen, H.-D.; Gao, X.; Morganti, G.; Febo, D. Chitin \& Lignin: Turning Food Waste into Cosmeceuticals. J. Clin. Cosmet. Dermatol. 2018, 3, 1-10. [CrossRef]

83. Morganti, P.; Yudin, V.E.; Morganti, G.; Coltelli, M.B. Trends in Surgical \& Beauty Masks for a Cleaner Environment. Cosmetics 2020, 7, 68. [CrossRef]

84. Morganti, P.; Muzzarelli, R.A.A.; Muzzarelli, C. Multifunctionl use of innovative chitin Nanofibrils for skin care. J. Appl. Cosmetol. 2006, 24, 105-114.

85. Ghosh, S. Composite non-woven in Medical applications. Comp. Non-Woven Mater. 2014, 211-224. [CrossRef]

86. Coltelli, M.B.; Aliotta, L.; Vannozzi, A.; Morganti, P.; Panariello, L.; Danti, S. Properties and Skin Compatibility of films Based on Poly (Lactic Acid) (PLA)Bionanocomposites Incorporating Chitin Nanofibrils (CN). J. Funct. Biomater. 2020, 11, 21. [CrossRef] [PubMed]

87. Azimi, B.; Thomas, L.; Fusco, A.; Kalaoglu-Altan, O.I.; Basneti, D.; Cinelli, P. Electrosprayed Chitin Nanofibril/Electrospun Polyhydroxyalkanoate Fiber Mesh as Functional Nonwoven for Skin Application. J. Funct. Biomater. 2020, 11, 62. [CrossRef] [PubMed] 
88. Muller, K.; Bugnicourt, E.; Latorre, M.; Jorda, M.; Sanz, Y.E.; Lagaron, J.M. Review on the Processing and Propertiss of Polymer Nanocomposites and Nanocoatings and their Applications in the Packaging, Automative and Solar Energy Fields. Nanomaterials 2017, 7, 74. [CrossRef] [PubMed]

89. Donnarumma, G.; Perfetto, B.; Baroni, A.; Paoletti, I.; Tufano, M.A.; Del Ciotto, P.; Morganti, P. Biological Activity of Innovative Polymeric Nanoparticles and Non-woven Tissue. In Bionanotechnology to Save the Environment; Morganti, P., Ed.; MDPI: Basel, Switzerland, 2019; pp. 321-339.

90. Boateng, J.S.; Matthews, K.H.; Stevens, H.N.E.; Eccleston, G.M. Wound Healing Dressings and Drug Delivery Systems: A Review. J. Pharm Sci. 2008, 97, 2892-2923. [CrossRef]

91. Dhivya, S.; Padma, V.V.; Santhim, E. Wound Dressings-A Review. Biomedicine 2015, 5, 24-28. [CrossRef]

92. Obisesan, K.A.; Neri, S.; Bugnicourt, E.; Campos, I.; Rodriguez-Turienzo, L. Determination and Quantification of the Distribution of CN-NL Nanoparticles Encapsulating Glycyrrhetic acid on Novel Textile Surfaces with Hyperspectral Imaging. J. Funct. Biomater. 2020, 11, 32. [CrossRef]

93. Panariello, L.; Vannozzi, A.; Morganti, P.; Coltelli, M.B.; Lazzeri, A. Biobased and Ecocomtatible Beauty Films Coated with Chitin Nanofibrils, Nanolignin and Vitamin, E. Cismetics 2021, 8, 27. [CrossRef]

94. Teno, J.; Pardo-Figuerez, M.; Hummel, N.; Bonin, V.; Fusco, A.; Ricci, C.; Donnarumma, G. Preliminary Studies on an Innovatve Bioactive Skin Soluble Beauty Mask Made by Combining Electrospinning and Dry Powder Impregnation. Cosmetics 2020, 7, 96. [CrossRef]

95. Yeung, O.; Johnston, H. Global Wellness Economy. Monitor Executive Summary, 2018. Available online: www.globalwellnessinstitute.org (accessed on 14 November 2021).

96. Roberts, R. Beauty Industry \& Cosmetics Marketing Statistics and Strategies for your Ecommerce Growth, Report by Thread Collective. 2021. Available online: www.commonthread.com (accessed on 14 November 2021).

97. Panico, A.; Serio, F.; Bagordo, F.; Grassi, T.; Idolo, A.; De Giorgi, M. Skin safety and health prevention: An overview of chemicals in cosmetic routs. J. Prev. Med. Yong. 2019, 60, 57-59. [CrossRef]

98. Steinsann, A.; Nematollah, N.; Rimachi, B.; Goodman, N.; Konev, S.D. Pandemic products and volatile emissions. Air Qual. Atmos. Health 2021, 14, 47-53. [CrossRef]

99. Morris, T. New Looks for for Male Personal Care. 2021 GWI Report; GWI: New York, NY, USA, 2021. Available online: https: //www.gwi.com/ (accessed on 14 November 2021).

100. Trifonova, V. The pursuit of purpose. How the pandemic has changed consumer's Approach to Life. Available online: https: //www.gwi.com/usa (accessed on 14 November 2021).

101. Russo, I.; Confente, I.; Scarpi, D.; Hazen, B.T. From trash to treasure; the Impact of consumer perceptions of bio-waste products in closed-loop supply chains. J. Clean. Prod. 2019, 218, 966-974. [CrossRef]

102. Pinto da Costa, J.; Rocha Santos, T.; Duarte, A.C. The environmental impacts of plastic and microplastics use, waste and pollution: EU and National measures. 2020 Report PE 658. 279 Policy Department of Citizens Rights and Constitutional Affairs-Directirate-General of Internal Policies. Available online: www.europarl.europa.eu (accessed on 14 November 2021).

103. Ahmed, S.; Stewart, A.; Smith, E.; Warne, T.; Byken, S. Consumer perception behaviours, and knowledge of food waste in a rural American state. Front. Sudtainable Food Syst. 2021, 5, 734785. [CrossRef]

104. Lindbom, H.; Olsson, A.; Williams, O. Consumer Perceptions of Food Packaging: Contributing to or Counteracting Environmentally Sustainable Developent? Pack Technol. Sci. 2015, 29, 3-23. [CrossRef]

105. Van Der Welf, P.; Gilliland, J.A. A systemic review of food loss and food waste generation in developing countries. Proc. Inst. Civ. Eng. Waste Resour. Manag. 2017, 170, 66-77.

106. Castrica, M.; Rebucci, R.; Gerolomini, C.; Tretola, M.; Cattaneo, D.; Baldi, A. Total phenolic and antioxidant capacity of agrifood waste and by-products. Ital. Anim. Sci. 2019, 18, 336-341. [CrossRef]

107. Biggs, E.M.; Bruce, E.; Boruff, B.; Duncan, J.M.A.; Horsley, J.; Paulj, N. Sustainable development and the water-energy-food nexus: A perspective on likelihoods. Env. Sci. Policy 2015, 54, 389-397. [CrossRef]

108. Zarei, S.; Bozorg-Haddad, O.; Singh, V.P.; Loaiciga, H.D. Developing water, energy and food sustainability performance indicators for agricultural systems. Sci. Rep. 2021, 11, 22831. [CrossRef]

109. Assas, M.A.; Kalantari, N.T.; Mohammadj-Ivatloo, B.; Safari, A. Sustainable management of the electric-energy-water-food nexus using robust optimization. Sustainability 2022, 14, 172. [CrossRef]

110. Sandri, I.G.; Piemolini-Barreto, L.T.; Roselei, C.F. Enzymes in Food Processing. In Biotechnology in Agriculture and Food Processing; Panesar, P.S., Marwaha, S.S., Eds.; CRC Press: Boca Raton, FL, USA, 2013; pp. 329-354.

111. Panesar, P.S.; Marwaha, S.S.; Panesar, R. Value Addition of Agro-Industrial Wastes and Residues. In Biotecnology in Agriculture and Food Processing; Panesar, P.S., Marwaha, S.S., Eds.; CRC Press: Boca Raton, FL, USA, 2014; pp. 557-605.

112. Gupta, J.; Kumari, M.; Mishra, A.; Swati, A.; Akram, M.; Thakur, I.S. Agro-forestry waste management-A review. Chemosphere 2022, 287, 132321. [CrossRef]

113. Murugan, K.; Ramasamy, K. Environmental Concerns and Sustainable Development. In Valorizatiin of Food Processing By-Products; Chandrasekaran, M., Ed.; CRC Press: Boca Raton, FL, USA, 2016; pp. 739-756.

114. Chandrasekaran, M. Future Prospects and the Need for Research. In Valorization of Food Processing By-Products; Chandrasekaran, M., Ed.; CRC Press: Boca Raton, FL, USA, 2016; pp. 757-771.

115. UN. Sustainable Development Goals; United Nations, Department of Economic and Social Affairs: New York, NY, USA, 2015. 
116. EMAF. Toward a Circular Economy: Business Rationale for an Accelerated Transition. Ellen McArthur Foundation, 2015. Available online: www.ellenmacarthurfoundation.org (accessed on 14 November 2021).

117. Vitella, M. Sustainable Finance for a Zero Waste Circular Economy, 2020 Zero Waste Europe. zerowasteeurope.eu, 2031 GWI Report; Zero Waste Europe: New York, NY, USA., 2020.

118. Lau, W.W.Y.; Shitan, Y.; Bailey, K.M.; Cook, E.; Stuchtey, M.; Koskella, J. Evaluating scenarios toward zero plastic pollution. Science 2020, 369, 1455-1461. [CrossRef]

119. Morganti, P. (Ed.) Bionanotechnology to Save the Environment; MDPI: Basel, Switzerland, 2019.

120. Morganti, P. (Ed.) An Introduction to the Circular Econom.my; NOVA Science Publishers: New York, NY, USA, 2021.

121. Calvo-Porral, C.; Ley-Mangin, J.P. The Circular Economy Business Model: Examining Consumer's Acceptance of Recycled Goods. Adm. Sci. 2020, 10, 28. [CrossRef]

122. Salas, D.A.; Criollo, P.; Ramirez, A.D. The Role of Higher Education Institutions in the Implementation of Circular Economy in Latin America. Sustainability 2021, 14, 9805. [CrossRef]

123. Liu, L.; Ramahrishna, S. (Eds.) An Introduction to Circular Economy; Springer: Singapore, 2021.

124. Laufenberg, G.; Kunz, B.; Nystroem, M. Transforming of vegetable waste into value added products: (A) the upgrading concept; (B) practical implementations. Bioresour. Technol. 2003, 87, 167-198. [CrossRef]

125. Mellou, F.; Varvaresou, A.; Papageorgiou, S. Renewable sources: Applications in personal care formulations. Int. J. Cos. Sci. 2019, 6, 517-525. [CrossRef] [PubMed]

126. Fermentino, G.; Asaduzzan, M.; Scampicchio, M.M. Current technologies and new insights for the recovery of high valuable compounds from fruit by-products. Crit. Rev. Food Sci. Nutr. 2016, 58, 386-404. [CrossRef]

127. Bags hold, I.; Arzoomand, N.S.; Boqvist, S. Food Security, Safety and Sustainability-Getting the Trade-Offs Right. Front. Sustain. Food Syst. 2020, 4, 16. [CrossRef]

128. Santos, P.V.; Marques, N.S.S.; Maia, P.C.S.V.; Barbosa de Lima, M.A.; De Oliveira Franci, L.; Campos-Takaki, G.M. Seafood waste as attractive source of chitin and chitosan production and their applications. Int. J. Mol. Sci. 2020, 21, 4290. [CrossRef]

129. Morganti, P.; Morganti, G.; Coltelli, M.B. Skin and Pollution:The smart nano-based cosmeceutical-tissues to save the planet' ecosystem. In Nanocosmetics:Fundamentals; Nanda, A., Nanda, S., Nguyen, T.A., Rajendran, S., Slimani, Y., Eds.; Elsevier: Amsterdam, Netherland, 2020; pp. 287-304. Available online: https://www.sciencedirect.com/science/article/pii/B97801282228 67000140 (accessed on 14 November 2021).

130. Morganti, P.; Morganti, G.; Colao, C. Biofunctional Textiles for Aging Skin. Biomedicines 2019, 7, 51. [CrossRef]

131. Morganti, P. Nanotechnology, Nanobiotechnology, and the Environment. In Bionanotechnology to Save the Environment; Morganti, P., Ed.; MDPI: Basel, Switzerland, 2019; pp. 3-9.

132. Collina, A. Sustainable Products: The Innovation Strategy for the European Chemjcal Industry. In Bioanotechnology to Save the Environment; Morganti, P., Ed.; MDPI: Basel, Switzerland, 2019; pp. 13-17.

133. Palmisano, P.; Piglione, M.C. Cellulose and Lignin: The Abundant Renewable Polymers from Plant Biomass. In Bionanotechnology to Save the Environment; Morganti, P., Ed.; MDPI: Basel, Switzerland, 2019; p. 82104.

134. Kunaver, M. Biomass Waste-ASource of Raw Materials. In Bionanotechnology to Save the Environment; Morganti, P., Ed.; MDPI: Basel, Switzerland, 2019; pp. 18-38.

135. Chen, H.-D.; Li, Y.H.; Morganti, P. Chitin-Hyaluronan Block Copolymeruc Nanoparticles for Innovative Cosmeceuticals. In Bionanotechnology to Save the Environment; Morganti, P., Ed.; MDPI: Basel, Switzerland, 2019; pp. 251-259.

136. Morganti, P.; Morganti, G. Circular and Green Economy: Which is The Difference? In An Introduction to the Circular Economy. Economic Issues, Problems and Perspectives; Morganti, P., Coltelli, M.B., Eds.; Nova Science Publishers: New York, NY, USA, 2021; pp. $17-40$.

137. Morganti, P.; Tischenko, G. Circular Economy for a Healthy Environment. In An Introduction to the Circular Economy. Economic Issues, Problems and Perspectives; Morganti, P., Coltelli, M.B., Eds.; Nova Science Publishers: New York, NY, USA, $2021 ;$ pp. 97-112.

138. Morganti, P.; Morganti, G.; Fusco, A.; Baroni, A. Waste Recycling for Wound care and Cosmetics Smart Bioeconomics: Chitin and Lignin. In Introduction to the Circular Economy. Economic Issues, Problems and Perspectives; Morganti, P., Coltelli, M.B., Eds.; Nova Science Publishers: New York, NY, USA, 2021; pp. 341-364.

139. Reichert, C.L.; Bugnicourt, E.; Coltelli, M.B.; Cinelli, P.; Lazzeri, A.; Canesi, I.; Braca, F.; Martínez, B.M.; Alonso, R.; Agostinis, L.; et al. Bio-based packaging: Materials, modifications, industrial applications and sustainability. Polymers 2020, 7, 1558. [CrossRef]

140. Nunez-Cacho, P.; Van der Gun, R.; Leyva-Diaz, J.C.; Molina-Moreno, V. Sustainable Food Production: Towards a Circular Economy of Plastic Food Packaging. In Introduction to the Circular Economy. Economic Issues, Problems and Perspectives; Morganti, P., Coltelli, M.B., Eds.; Nova Science Publishers: New York, NY, USA, 2021; pp. 243-2601.

141. Vukovic, N.A. Reuse and Recycling of Post-Consumer Textile Waste in Smart Green Cities. In Introduction to the Circular Economy. Economic Issues, Problems and Perspectives; Morganti, P., Coltelli, M.B., Eds.; Nova Science Publishers: New York, NY, USA, 2021; pp. 391-404.

142. Hundertmar, K.T.; Mayer, M.; McNelly, C.; Simons, T.S.; Witte, C. How plastics waste recycling could transform the chemical Industry, 2018. McKinsey and Company. Available online: https://www.mckinsey.com/industries/chemicals/our-insights / how-plastics-waste-recycling-could-transform-the-chemical-industry (accessed on 14 November 2021). 
143. Morganti, P.; Vannozzi, A.; Memic, A.; Coltelli, M.B. Chitin and Lignin waste in The Circular Economy. In Introduction to the Circular Economy. Economic Issues, Problems and Persp. Ectives; Morganti, P., Coltelli, M.B., Eds.; Nova Science Publishers: New York, NY, USA, 2021; pp. 281-296.

144. Morganti, P.; Morganti, G.; Palombo, M. Research and Innovation for Sustainable Products: Polysaccharides for a Smart Circular Economy at zero Waste. Clin. Res. Clin. Trials 2021, 3, 37. [CrossRef]

145. Morganti, P.; Morganti, G.; Nemic, A.; Coltelli, M.B.; Chen, H.-D. The New Renaissance of Beauty and Wellness through the Green Economy. Latest Trends Text. Fash. Des. 2021, 4, 749-760. [CrossRef]

146. Morganti, P.; Morganti, G.; Gagliardini, A.; Lohani, A. From Cosmertics to Innovative Cosmeceuticals-Non-wuven Tissues as New Biodegradable Carriers. Cosmetics 2021, 8, 65. [CrossRef]

147. Vukovic, N.A.; Larconova, V.A.; Morganti, P. Smart Sustainable Cities: Smart Approaches and Analysis. Ekon. Reg. 2021, 17, 1004-1013. [CrossRef] 